ZRC SAZU, UMETNOSTNOZGODOVINSKI INŠTITUT FRANCETA STELETA

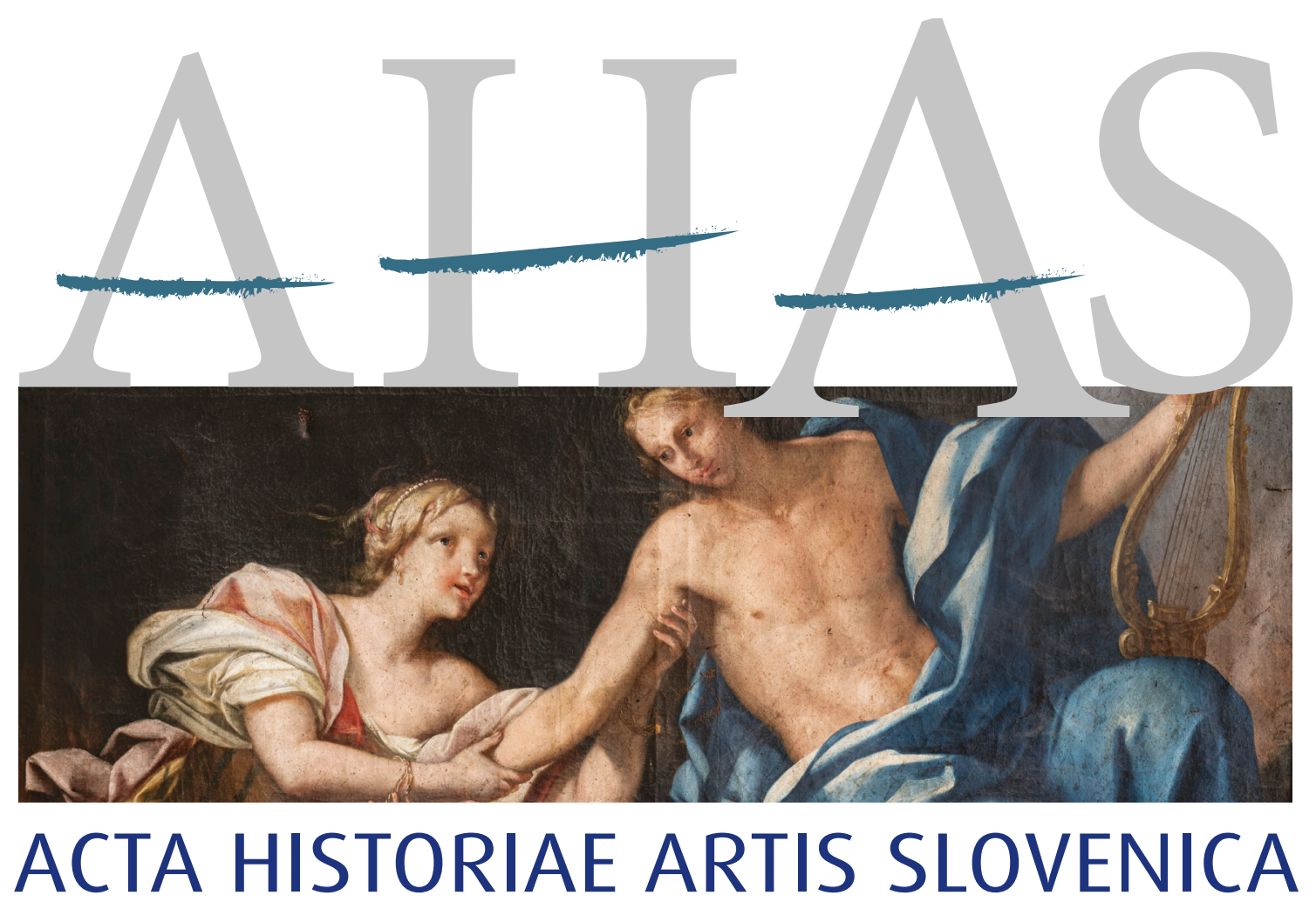

Frančišek Karel Remb in slikarstvo

v habsburških dednih deželah okrog leta 1700

Franz Carl Remp and Painting in the Habsburg Hereditary Lands around 1700

Franz Carl Remp und die Malerei in den habsburgischen Erblanden um 1700

$$
26 \mid 2 \cdot 2021
$$




\section{ACTA HISTORIAE ARTIS SLOVENICA $26 \mid 2 \cdot 2021$}

Frančišek Karel Remb in slikarstvo v habsburških dednih deželah okrog leta 1700

Franz Carl Remp and Painting in the Habsburg Hereditary Lands around 1700

Franz Carl Remp und die Malerei in den habsburgischen Erblanden um 1700 
Acta historiae artis Slovenica, 26/2, 2021

Frančišek Karel Remb in slikarstvo v habsburških dednih deželah okrog leta 1700

Franz Carl Remp and Painting in the Habsburg Hereditary Lands around 1700

Franz Carl Remp und die Malerei in den habsburgischen Erblanden um 1700

Znanstvena revija za umetnostno zgodovino / Scholarly Journal for Art History

ISSN 1408-0419 (tiskana izdaja / print edition) ISSN 2536-4200 (spletna izdaja / web edition)

ISBN 978-961-05-0568-6

Izdajatelj / Issued by

ZRC SAZU, Umetnostnozgodovinski inštitut Franceta Steleta /

ZRC SAZU, France Stele Institute of Art History

Založnik / Publisher

Založba ZRC

Urednika / Edited by

Edgar Lein, Polona Vidmar

Uredniški odbor / Editorial board

Renata Komić Marn, Tina Košak, Katarina Mohar, Mija Oter Gorenčič, Blaž Resman, Helena Seražin

Mednarodni svetovalni odbor / International advisory board

Günter Brucher (Salzburg), Ana María Fernández García (Oviedo), Hellmut Lorenz (Wien),

Milan Pelc (Zagreb), Sergio Tavano (Gorizia-Trieste), Barbara Wisch (New York)

Lektoriranje / Language editing

Oliver Currie, Manuela Dajnko, Andrea Leskovec

Prevodi / Translations

Alan Harvey Cook, Blaž Resman, Nika Vaupotič, Polona Vidmar

Celostni strokovni in jezikovni pregled / Expert and language editing

Blaž Resman

Oblikovna zasnova in prelom / Design and layout

Andrej Furlan

Naslov uredništva / Editorial office address

Acta historiae artis Slovenica

Novi trg 2, p. p. 306, SI -1001 Ljubljana, Slovenija

ahas@zrc-sazu.si; https://ojs.zrc-sazu.si/ahas

Revija je indeksirana v / Journal is indexed in

Scopus, ERIH PLUS, EBSCO Publishing, IBZ, BHA

Letna naročnina / Annual subscription: $35 €$

Posamezna enojna številka / Single issue: $25 €$

Letna naročnina za študente in dijake: $25 €$

Letna naročnina za tujino in ustanove / Annual subscription outside Slovenia, institutions: $48 €$

Naročila sprejema / For orders contact

Založba ZRC

Novi trg 2, p. p. 306, SI-1001, Slovenija

E-pošta / E-mail: zalozba@zrc-sazu.si

AHAS izhaja s podporo Javne agencije za raziskovalno dejavnost Republike Slovenije.

AHAS is published with the support of the Slovenian Research Agency.

(c) 2021, ZRC SAZU, Umetnostnozgodovinski inštitut Franceta Steleta, Založba ZRC, Ljubljana Tisk / Printed by Collegium Graphicum d.o.o., Ljubljana

Naklada / Print run: 400 


\section{VSEBINA \\ Contents}

Edgar Lein, Polona Vidmar

Frančišek Karel Remb in slikarstvo v habsburških dednih deželah okrog leta 1700. Predgovor ...........................5

Franz Carl Remp and Painting in the Habsburg Hereditary Lands around 1700. Preface .....................................7

Franz Carl Remp und die Malerei in den habsburgischen Erblanden um 1700. Vorwort .....................................9

\section{DISSERTATIONES}

Karin Požin

Remp's Ceiling Paintings in the Palais Attems in Graz. From Reproductive Prints to Frescoes

Rembove stropne poslikave v graški palači Attems. Od grafičnih predlog do fresk ...13

Georg Lechner

Franz Carl Remp zwischen Graz und Wien 31

Frančišek Karel Remb med Gradcem in Dunajem 48

Edgar Lein

Preis und Wert der Malerei um 1700. Zu den Kosten von Gemälden in der Steiermark 51

Cena in vrednost slik okrog leta 1700. O stroških za slike na Štajerskem

Renata Komić Marn

Zaplemba - prenos - distribucija. Slike grofa Attemsa iz gradu Slovenska Bistrica $v$ slovenskih javnih zbirkah

Confiscation - Transfer - Distribution. Count Attems' Paintings from

Slovenska Bistrica Castle in Slovenian Public Collections

Polona Vidmar

Emblematische Gratulationsschriften, Stammbäume und Porträts

von Dominik Franz Calin von Marienberg für das Haus Habsburg.

Emblematična voščila, rodovniki in portreti Dominika Frančiška Kalina

von Marienberga za Habsburžane

Ulrich Becker

Weltgeschichte im Wimmelbild. Stephan Kessler und der Entsatz von Wien 1683.

Svetovna zgodovina na »mrgoleči sliki«. Stephan Kessler in Rešitev Dunaja leta 1683 
Andreas Gamerith

Zeit des Experiments. Die Galleria maior des Stiftes Zwettl als Beispiel

für seicenteske Wandmalerei in Niederösterreich.

Čas eksperimentiranja. Galleria maior v samostanu Zwettl

kot primer stenskega slikarstva 17. stoletja v Spodnji Avstriji

\section{Martin Mádl}

The Patterns of the Transformation in Central European Ceiling Painting

around 1700 and Franz Carl Remp in Brežice Castle.

Vzorci transformacije v srednjeevropskem stropnem slikarstvu okrog leta 1700

in Frančišek Karel Remb v brežiškem gradu 


\section{Predgovor}

\section{FranČIŠEK KAREL REMB IN SLIKARSTVO V HABSBURŠKIH DEDNIH DEŽELAH OKROG LETA 1700}

Kljub razmeroma številnim slikam je ostal opus v Radovljici rojenega ter v Gradcu in na Dunaju delujočega slikarja Frančiška Karla Remba (1675-1718) široki javnosti doslej večinoma neznan. Prva in zaenkrat edina razstava Rembovih del je bila od 26. oktobra 1973 do 19. maja 1974 na ogled v Spodnjem Belvederu na Dunaju ter junija 1974 v vogalni sobi Stare galerije muzeja Joanneum v graški Neutorgasse. Razstavni katalog z naslovom Der Barockmaler Franz Carl Remp 1674-1718 vsebuje sedem strani obsegajoč uvod v umetnikovo življenje in delo, kataložni del z dvajsetimi enotami, časovnico in seznam literature.

Georg Lechner se je s Frančiškom Karlom Rembom ukvarjal v okviru svoje leta 2010 na Dunaju obranjene doktorske disertacije. Ko je spomladi 2018 Lechner opozoril, da se jeseni bliža tristota obletnica Rembove smrti, vendar ni niti na Dunaju niti v Gradcu načrtovana kakšna razstava slikarjevih del, smo se odločili za organizacijo simpozija, ki je pod naslovom Slikarji in naročniki. Frančišek Karel Remb in slikarstvo na Štajerskem okrog 1700 potekal 23. novembra 2018 v Laterneng'wölb dvorca Eggenberg. Naslednji dan so si udeleženci pod vodstvom Georga Lechnerja ogledali palačo Attems in pod vodstvom Paula Schusterja reprezentativne prostore dvorca Eggenberg. Simpozij so podprli univerzi v Gradcu in Mariboru ter Znanstvenoraziskovalni center Slovenske akademije znanosti in umetnosti, Umetnostnozgodovinski inštitut Franceta Steleta. Bil je del bilateralnega projekta BI SLO-AT/16-17-18: Umetnostni naročniki kot nosilci deželne identitete. Vloga in pomen naročnikov za gradnjo in opremo plemiških rezidenc in romarskih središč na Štajerskem, ki sta ga financirala Javna agencija za raziskovalno dejavnost Republike Slovenije in Österreichischer Austauschdienst, ter temeljnega raziskovalnega projekta J6-7410: Umetnostna reprezentacija plemstva. Naročništvo na Štajerskem $v$ zgodnjem novem veku (2016-2018), ki ga je financirala Javna agencija za raziskovalno dejavnost Republike Slovenije.

Simpozij so otvorili Georg Lechner s temeljnim prispevkom o Frančišku Karlu Rembu med Gradcem in Dunajem (Franz Carl Remp zwischen Graz und Wien), Christine Rabensteiner, ki je predstavila dela priseljenih in na Štajerskem rojenih baročnih slikarjev v depojih graške Stare galerije (Werke immigrierter und gebürtiger steirischer Barockmaler. Ein Blick in das Depot der Alten Galerie), ter Karin Požin s študijo o Rembovih stropnih poslikavah v palači Attems v Gradcu in likovnih virih zanje (Case Study of Remp's Ceiling Paintings in Palais Attems in Graz. From Reproductive Prints to Frescoes). V drugem delu je Edgar Lein predstavil ceno in vrednost slikarskih del okrog 1700 (Preis und Wert der Malerei um 1700), Tina Košak pa je na podlagi virov v mestnem arhivu v Antwerpnu raziskala trgovce $\mathrm{z}$ umetninami iz družine Forchondt in njihove štajerske stranke (The Forchondt Art Dealers and their Styrian Clients. Excerpts from the Antwerp City Archives). Renata Komić Marn je analizirala portrete Eleonore Marije Rozalije kneginje Eggenberg (The Portraits of Eleonora Maria Rosalia Princess of Eggenberg), Polona Vidmar pa je predstavila slikane genealogije štajerskega plemstva okrog leta 1700 (Gemalte Genealogien des steirischen Adels um 1700). Meje historične Štajerske so s svojimi referati presegli Ulrich Becker, ki je Stephanu Kesslerju pripisal upodobitvi Rešitve 
Dunaja leta 1683 (Weltgeschichte als Wimmelbild. Stephan Kessler und der Entsatz von Wien 1683), Andreas Gamerith, ki se je ukvarjal s stropnimi poslikavami pred Trogerjem oziroma okrog leta $1700 \mathrm{v}$ samostanih Zwettl in Altenburg (Vor Troger. Aspekte der Wandmalerei um 1700 am Beispiel der Klöster Zwettl und Altenburg), ter Martin Mádl z izčrpnim predavanjem o češkem stropnem slikarstvu okoli 1700 („So ist nun ... der Pracht im Bauen so hoch gestiegen ..... Profane Ceiling Painting in Bohemia around 1700).

Udeleženci simpozija so svoje referate pripravili za tisk ali pa so prispevali nova raziskovalna spoznanja, ki jih v Acta historiae artis Slovenica objavljamo pod naslovom Frančišek Karel Remb in slikarstvo v habsburških dednih deželah okrog leta 1700. Prispevka Karin Požin in Georga Lechnerja poglabljata vedenje o Rembovih stenskih poslikavah v palači Attems in o delih, ki jih je ustvaril po selitvi na Dunaj. Nekatere Rembove oljne slike so obravnavane tudi v prispevkih Edgarja Leina, ki se je posvetil stroškom za slike na Štajerskem, ter Renate Komić Marn, ki je raziskala slike iz Attemsove zbirke v Slovenski Bistrici v slovenskih javnih zbirkah. Slikarstvo zadnjih desetletij 17. stoletja je tema prispevkov Polone Vidmar, ki se je posvetila delom Dominika Frančiška Kalina von Marienberga za Habsburžane, in Ulricha Beckerja, ki je upodobitvi Rešitve Dunaja atribuiral tirolskemu slikarju Stephanu Kesslerju. Andreas Gamerith je Gallerio maior v samostanu Zwettl predstavil kot eksperiment v stropnem slikarstvu poznega 17. stoletja v Spodnji Avstriji, zvezek pa zaključuje prispevek Martina Mádla, ki se je posvetil transformaciji srednjeevropskega slikarstva okrog leta 1700 in pomembnim zgledom zanjo.

Upava, da bodo raznoliki prispevki in številne upodobitve spodbudili nadaljnje raziskovanje baročnega slikarstva. 


\section{Preface}

\section{Franz Carl Remp and Painting in THE HABSbURg Hereditary LANDS AROUND 1700}

The oeuvre of Radovljica born painter Franz Carl Remp (1675-1718) who worked in Graz and Vienna is little-known to the wider public despite his relatively numerous paintings. The first and only exhibition of Remp's works up to now was held from 26 October 1973 to 19 May 1974 at the Lower Belvedere in Vienna, and in the corner room of the present-day Universalmuseum Joanneum's Alte Galerie in Neutorgasse in Graz in June 1974. The exhibition catalogue entitled Der Barockmaler Franz Carl Remp 1674-1718 includes a seven-page introduction to the artist's life and work, a catalogue comprising twenty units, a chronology, and list of sources.

Georg Lechner researched Franz Carl Remp in his PhD thesis, which he defended 2010 in Vienna. In the spring of 2018, Lechner drew attention to the fact that the $300^{\text {th }}$ anniversary of the painter's death would occur in the autumn of the same year, and that neither Vienna nor Graz planned to commemorate the anniversary with an exhibition of the Baroque painter's works. We therefore decided to organize a conference entitled Painters and Patrons. Franz Carl Remp and Painting in Styria around 1700 that was held on 23 November 2018 at the Laterneng'wölb in the Eggenberg Castle. The following day the participants went on a tour of the Palais Attems, guided by Georg Lechner, as well as a tour of Eggenberg Castle's monumental rooms guided by Paul Schuster. The conference was supported by the Universities of Graz and Maribor, and the Research Centre of the Slovenian Academy of Sciences and Arts, the France Stele Institute of Art History. It formed part of the bilateral project BI SLO-AT/16-17-18: Art Patrons as Carriers of Province's Identity. The Role and Significance of Commissioners of Architectures and Furnishings of Aristocratic Residences and Pilgrimage Sites in Styria, which was financed by the Slovenian Research Agency and the Österreichischer Austauschdienst, and the research project J6-7410: Visual Representations of the Nobility. Early Modern Art Patronage in the Styria Province (2016-2018), financed by the Slovenian Research Agency.

The conference opened with Georg Lechner's general and foundational contribution - Franz Carl Remp between Graz and Vienna (Franz Carl Remp zwischen Graz und Wien) - followed by Christine Rabensteiner, who presented the works of immigrant and Styria-born Baroque painters in storage in the Alte Galerie in Graz (Werke immigrierter und gebürtiger steirischer Barockmaler. Ein Blick in das Depot der Alten Galerie), and Karin Požin with her study of Remp's ceiling paintings in Palais Attems in Graz and their sources (Case Study of Remp's Ceiling Paintings in Palais Attems in Graz. From Reproductive Prints to Frescoes). In the second part of the conference there were papers on the wider context and Styrian art of the period. Edgar Lein gave a spech on the cost and value of paintings around 1700 (Preis und Wert der Malerei um 1700). Tina Košak presented a study of the art dealers from the Forchondt family and their Styrian clients based on sources in the Antwerp city archives (The Forchondt Art Dealers and their Styrian Clients. Excerpts from the Antwerp City Archives). Renata Komić Marn analysed the portraits of Eleonora Maria Rosalia Princess of Eggenberg (The Portraits of Eleonora Maria Rosalia Princess of Eggenberg), and Polona Vidmar presented the painted genealogies of Styrian nobility around 1700 (Gemalte Genealogien des steirischen Adels um 
1700). The final section of the conference went beyond the borders of historical Styria: Ulrich Becker attributed the depictions of the Liberation of Vienna in 1683 to Stephan Kessler (Weltgeschichte als Wimmelbild. Stephan Kessler und der Entsatz von Wien 1683); Andreas Gamerith dealt with ceiling paintings in the Zwettl and Altenburg monasteries before Troger (Vor Troger. Aspekte der Wandmalerei um 1700 am Beispiel der Klöster Zwettl und Altenburg), and Martin Mádl gave a detailed paper on Czech ceiling painting around 1700 („So ist nun ... der Pracht im Bauen so hoch gestiegen .... Profane Ceiling Painting in Bohemia around 1700).

The conference participants prepared their papers for publication, or contributed new research findings, which are now being published in the Acta historiae artis Slovenica under the title Franz Carl Remp and Painting in the Habsburg Hereditary Lands around 1700. The contributions by Karin Požin and Georg Lechner deepen our knowledge of Remp's ceiling paintings in the Palais Attems, as well of the works he created after moving to Vienna. Some of Remp's oil paintings are also treated in the papers by Edgar Lein, who focuses on the cost of paintings in Styria, and by Renata Komić Marn, who discusses the paintings from the Attems collection in Slovenska Bistrica in Slovenian public collections. The topic of the papers by Polona Vidmar, who focuses on Dominik Franz Kalin von Marienberg's works for the Habsburg family, and Ulrich Becker, who attributes the depictions of the Liberation of Vienna to Tyrolian painter Stephan Kessler, is the painting of the last decades of the $17^{\text {th }}$ century. Andreas Gamerith discusses the Galleria maior in the Zwettl monastery as an experiment in ceiling painting in late $17^{\text {th }}$ century Lower Austria. The volume is concluded by Martin Mádl's contribution, which focuses on the transformation of Central European painting around 1700 and the models that were important for this transformation.

We hope that the diverse contributions and the numerous depictions will encourage further research in Baroque painting. 


\section{VORWORT}

\section{Franz CARl Remp UNd die MAlerei IN DEN HABSBURGISCHEN ERBLANDEN \\ UM 1700}

Trotz einer relativ großen Anzahl von Gemälden ist das CEuvre des in Radovljica in Slowenien geborenen und in Graz sowie Wien tätigen Malers Franz Carl Remp (1675-1718) einer breiten Öffentlichkeit bislang weitgehend unbekannt geblieben. Die erste und bislang einzige Ausstellung mit Werken des Malers wurde vom 26. Oktober 1973 bis zum 19. Mai 1974 im Unteren Belvedere in Wien und im Juni 1974 im Ecksaal der Alten Galerie des Joanneums in der Grazer Neutorgasse gezeigt. Das Katalogbändchen mit dem Titel Der Barockmaler Franz Carl Remp 1674-1718 enthält eine sieben Seiten umfassende Einführung zu Leben und Werk des Künstlers, einen Katalogteil mit zwanzig Einträgen, eine Zeittafel und ein Literaturverzeichnis.

Georg Lechner hat sich im Rahmen seiner 2010 in Wien abgeschlossenen Dissertation umfassend mit Franz Carl Remp befasst. Als Lechner im Frühjahr 2018 darauf hinwies, dass sich der 300. Todestag des Malers im Herbst nähere, aber weder in Wien noch in Graz eine Ausstellung mit Werken des Barockmalers geplant sei, beschlossen die Herausgeber, eine Tagung zu organisieren, die am 23. November 2018 unter dem Titel Maler und Auftraggeber. Franz Carl Remp und die Malerei in der Steiermark um 1700 im Laterneng'wölb von Schloss Eggenberg abgehalten wurde. Ergänzend dazu gab es am darauffolgenden Tag eine Besichtigung des Palais Attems unter der Leitung von Georg Lechner sowie eine Führung von Paul Schuster durch die Prunkräume von Schloss Eggenberg. Die von den Universitäten in Graz und Maribor sowie dem France Stele Institut für Kunstgeschichte am Forschungszentrum der Slowenischen Akademie der Wissenschaften und Künste unterstützte Veranstaltung war Teil des von der Slowenischen Forschungsagentur und dem Österreichischen Austauschdienst finanzierten bilateralen Projekts BI SLO-AT/16-17-18: Art Patrons as Carriers of Province's Identity. The Role and Significance of Commissioners of Architectures and Furnishings of Aristocratic Residences and Pilgrimage Sites in Styria sowie des von der Slowenischen Forschungsagentur finanzierten Forschungsprojekts J6-7410: Visual Representations of the Nobility. Early Modern Art Patronage in the Styria Province (2016-2018).

Den Anfang der Tagung machten Georg Lechner mit einem grundlegenden Vortrag über Franz Carl Remp zwischen Graz und Wien und Christine Rabensteiner mit Werke immigrierter und gebürtiger steirischer Barockmaler. Ein Blick in das Depot der Alten Galerie sowie Karin Požin mit einer Case Study of Remp's Ceiling Paintings in Palais Attems in Graz. From Reproductive Prints to Frescoes. Im zweiten Teil untersuchten Edgar Lein Preis und Wert der Malerei um 1700 und Tina Košak The Forchondt Art Dealers and their Styrian Clients. Excerpts from the Antwerp City Archives. Renata Komić Marn analysierte The Portraits of Eleonora Maria Rosalia Princess of Eggenberg und Polona Vidmar präsentierte Gemalte Genealogien des steirischen Adels um 1700. Den Blick über die Steiermark hinaus weiteten Ulrich Becker mit seinem Vortrag Weltgeschichte als Wimmelbild. Stephan Kessler und der Entsatz von Wien 1683, Andreas Gamerith mit einem Blick auf die Malerei Vor Troger. Aspekte der Wandmalerei um 1700 am Beispiel der Klöster Zwettl und Altenburg und Martin Mádl mit einem umfassenden Vortrag zum Thema „So ist nun ... der Pracht im Bauen so hoch gestiegen ..... Profane Ceiling Painting in Bohemia around 1700. 
Die Referenten und Referentinnen überarbeiteten ihre Vorträge für die Drucklegung oder präsentierten neue Forschungsergebnisse, die wir in den Acta historiae artis Slovenica unter dem Titel Franz Carl Remp und die Malerei in den habsburgischen Erblanden um 1700 veröffentlichen. Die Beiträge von Karin Požin und Georg Lechner erweitern das Wissen über Remps Wandmalereien im Palais Attems und über sein nach der Übersiedlung nach Wien geschaffenes Werk. Einige Ölgemälde Remps werden auch in den Beiträgen von Edgar Lein, der sich den Kosten für Gemälde in der Steiermark widmet, und Renata Komić Marn, die die Gemälde der ursprünglich in Schloss Slovenska Bistrica befindlichen Sammlung Attems in slowenischen öffentlichen Sammlungen untersucht, behandelt. Die Malerei in den letzten Jahrzehnten des 17. Jahrhunderts ist das Thema der Beiträge von Polona Vidmar, die die Werke Dominik Franz Calins von Marienberg für das Haus Habsburg präsentiert, und Ulrich Becker, der zwei Darstellungen des Entsatzes von Wien dem Tiroler Maler Stephan Kessler zuschreibt. Andreas Gamerith thematisiert die Galleria maior in Stift Zwettl als ein Experiment der Deckenmalerei des späten 17. Jahrhunderts in Niederösterreich. Der Band endet mit dem Beitrag von Martin Mádl, der sich der Transformation der mitteleuropäischen Wandmalerei um 1700 und ihren bedeutenden Vorbildern widmet.

Wir hoffen, dass die vielfältigen Beiträge und die zahlreichen Abbildungen zu einer weiteren Beschäftigung mit der Barockmalerei anregen werden.

Edgar Lein, Polona Vidmar 


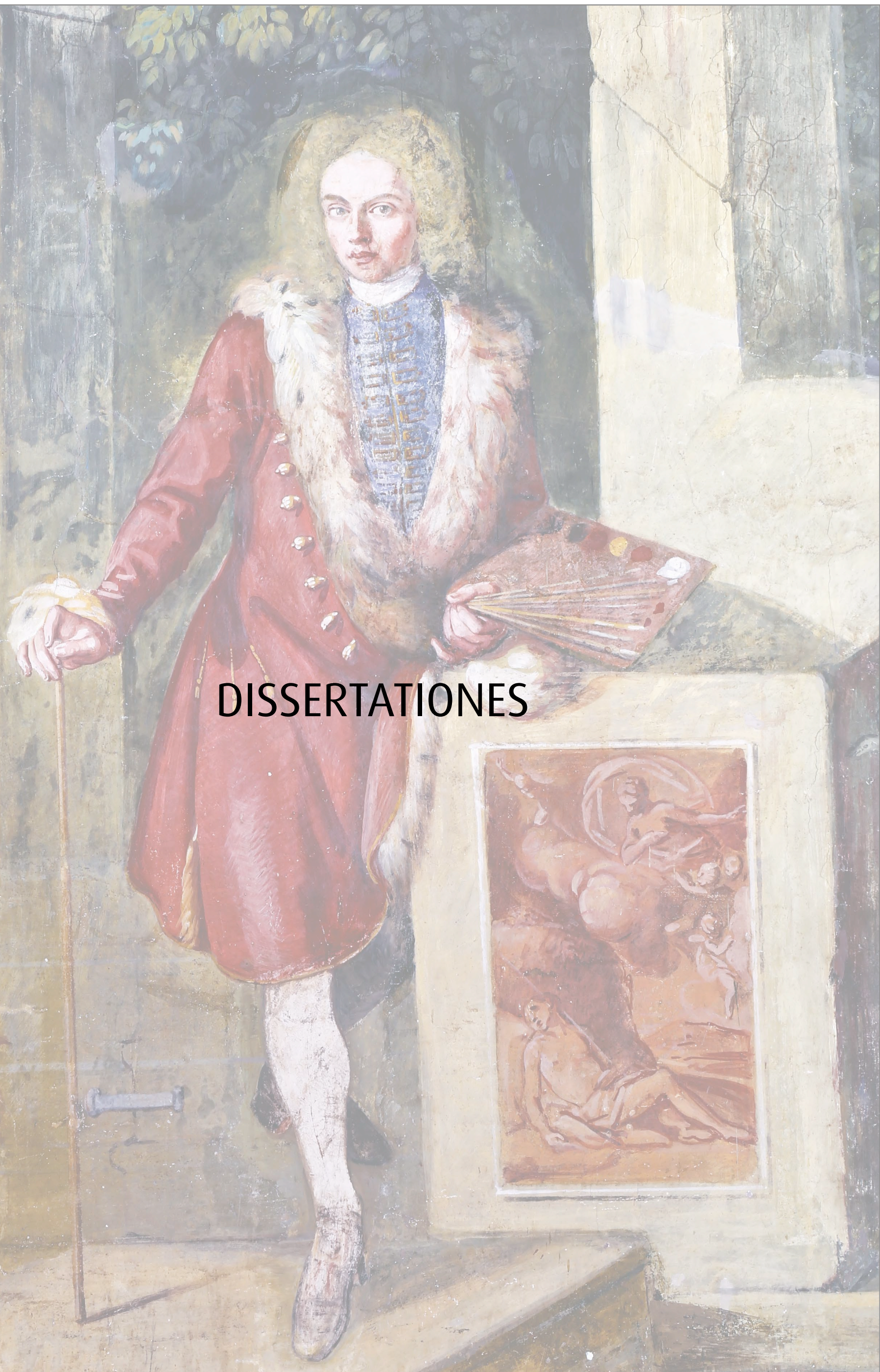




\title{
Weltgeschichte im Wimmelbild
}

\author{
Stephan Kessler und der Entsatz von Wien 1683
}

\author{
Ulrich Becker \\ Dr. Ulrich Becker, Universalmuseum Joanneum, Graz, \\ Museum für Geschichte, Kulturhistorische Sammlung, Sackstraße 16, A-8010 Graz, \\ ulrich.becker@museum-joanneum.at
}

Izvleček:

Svetovna zgodovina na »mrgoleči sliki«. Stephan Kessler in Rešitev Dunaja leta 1683

1.01 Izvirni znanstveni članek

Panoramske upodobitve bitk so bile v slikarstvu 17. stoletja zelo razširjen žanr; v njem izurjeni slikarji so postali iskani specialisti, delujoči za številne srednjeevropske dvore. Zaradi stalnih turških napadov so postale upodobitve bitk v 17. stoletju ponovno aktualne in dosegle visoko kakovostno raven. Kljub oddaljenosti od velikih umetnostnih središč, a dobro seznanjen z njihovimi dosežki, si je Stephan Kessler, slikar poznega 17. stoletja iz južnotirolskega Briksna, uspešno utrl pot na tem področju $z$ upodobitvama osvoboditve Dunaja leta 1683 na barvitih mnogofiguralnih platnih v tradiciji »mrgolečih slik« (Wimmelbilder) 16. stoletja. Kot umetnik skromnih talentov se je Kessler redno opiral na Rubensa, čigar kompozicije so na novo zaživele s pomočjo dobro znanih prevodnih grafik.

Kesslerju sta bili pripisani upodobitev bitke pred Dunajem leta 1683 v Vojnozgodovinskem muzeju na Dunaju in slika istega motiva v gradu Friedenstein v Gothi, ki je dunajskemu platnu tudi slogovno zelo blizu. Atribucijo je potrdil Kesslerjev monogram, najden med nedavno raziskavo na dunajski sliki.

Ključne besede: upodobitve bitk, historično slikarstvo, slikarstvo 17. stoletja, vojne s Turki, prevodna grafika, Rubens, provincialna umetnost

\begin{abstract}
:
The History of the World in a 'Wimmelbild'. Stephan Kessler and the Liberation of Vienna in 1683

1.01 Original scientific article

The representation of battle panoramas was a widespread genre in $17^{\text {th }}$-century painting when skilled artists became sought-after specialists working for many courts in Central Europe. Throughout the $17^{\text {th }}$ century, continual Ottoman aggressions gave a new actuality to the battle genre. Stephan Kessler, a late $17^{\text {th }}$-century artist from the South Tyrolean town of Brixen, who lived far away from the great artistic centres, but was well informed of developments there, successfully made his way in this field, depicting the liberation of Vienna in 1683 on colourful, multi-figured canvasses in the tradition of $16^{\text {th }}$-century 'Wimmelbilder'. As an artist of modest talents, Kessler regularly referred to Rubens, whose compositions came to new life through well-known reproductive prints. A representation of the Vienna battle from 1683 held at the Heeresgeschichtliches Museum, Vienna, was attributed to Kessler, as well as a stylistically closely related painting of the same motif at Schloss Friedenstein, Gotha. Recent research of the Viennese canvas confirmed this hypothesis when Kessler's monogram came to light.
\end{abstract}

Keywords: battle painting, historical painting, $17^{\text {th }}$-century painting, Ottoman wars, reproduction prints, Rubens, provincial art 
Mit seiner detailfreudigen Erzählweise behauptet das Oeuvre des Südtirolers Stephan Kessler (1622-1700) einen eigenständigen Platz innerhalb der österreichischen Barockmalerei. ${ }^{1}$ Spuren von Kesslers Wirken finden sich, wiewohl sporadisch, auch in der Steiermark, so in der ehemaligen Dominikanerkirche St. Andrä in Graz. ${ }^{2}$

Der Hang zum Detail in Kesslers Werk verbindet sich regelmäßig mit einem überbordenden, den Betrachter mitunter verwirrenden Figurenreichtum, der den Künstler als kundigen Regisseur dramatischer Historienszenen ausweist und in die Nachfolge des traditionellen flämischen „Wimmelbildes" stellt. Dieser im 16. Jahrhundert zu voller Entfaltung gelangte Bildtypus zeichnet sich durch extrem volkreiche, zu genauer Bildlektüre einladende Szenen aus, wie sie sowohl bei sakralen Sujets, etwa bei Passionszyklen Antwerpener Schnitzaltäre, als auch bei profanen Historien, man denke allein an Albrecht Altdorfers Alexanderschlacht, den Kompositionen ihr Gepräge gaben.

Auf diese Weise hat Kessler das Dokumentations- und Memorialbedürfnis seiner Auftraggeber souverän zu befriedigen gewusst. Offensichtlich wog diese besondere, von den Zeitgenossen geschätzte Qualität mehr als jene unleugbaren ausführungstechnischen Defizite, die für Kesslers Werk durchweg charakteristisch sind.

Dem Umstand, dass Kesslers Talent rasch an seine Grenzen stieß, mag ein heutiger, an plakative Bilderflut gewöhnter Betrachter durchaus Charme abgewinnen und dabei die unübersehbare Diskrepanz goutieren, wie sie gerade im Falle Kesslers zwischen Können und Wollen besteht. Ihren Anteil haben daran nicht zuletzt die ausgiebig zitierten Pathosformeln, die in den allermeisten Fällen keiner geringeren Autorität als Peter Paul Rubens zu verdanken sind. ${ }^{3}$ Der hier greifbare, nahezu unerschöpflich scheinende Motivschatz forderte zum Rekurs förmlich heraus. Ermöglicht wurde dieses Verfahren durch eine omnipräsente Reproduktionsgrafik auf höchstem Niveau. ${ }^{4}$ Kessler hat nicht gezögert, diese überaus suggestiven Vorlagen heranzuziehen und je nach Thema $\mathrm{zu}$ adaptieren. Diese unbefangene, ebenso zeittypische wie vom Plagiatsvorwurf völlig freie Praxis versetzte ihn in die Lage, umfangreiche wie komplexe Aufträge zu bewältigen sowie - ungeachtet aller künstlerischen Schwächen - als versierter Vertreter seines Faches, als pictor doctus, zu erscheinen, der ein breites, nicht nur auf einer einzigen Autorität basierendes Vorbildwissen bewies. Kein anderer als Rubens selbst war ihm darin vorangegangen. ${ }^{5}$

In diesen Kontext gehört die Schilderung eines Ereignisses von weltgeschichtlicher Tragweite, des Entsatzes von Wien 1683, der die „Zweite Wiener Türkenbelagerung“ und damit die über Jahrhunderte währende Serie osmanischer Vorstöße nach Mitteleuropa beendete. Die definitive Entscheidung brachte jene von Papst Innozenz XI. finanzierte militärische Intervention, die unter maßgeblicher Beteiligung des polnischen Königs Jan III. Sobieski sowie mehrerer Reichsfürsten zustande kam und dabei die nachgeordnete Rolle des Hauptbetroffenen, Kaiser Leopold I., in einer für diesen peinlichen Weise unterstrich. Gleichwohl stellte der solcherart erkämpfte Sieg für alle

1 Umfassend dazu: Stephan Kessler 1622-1700. Ein Tiroler Maler der Rubenszeit (Hrsg. Leo Andergassen, Helmut Stampfer), Diözesanmuseum Brixen, Brixen 2005.

2 Reinfried LIEBMINGER, Das Martyrium des Hl. Andreas von Stephan Kessler. Das Hochaltarbild in der Grazer Pfarrkirche St. Andrä, Graz 2017 (unpublizierte Masterarbeit).

3 Ulrich BECKER, Pathosformel und Reproduktion. Beobachtungen zum Nachleben von Peter Paul Rubens im Oeuvre von Stephan Kessler, Stephan Kessler 2005 (Anm. 1), S. 15-23.

4 Peter Paul Rubens 1577-1640. Katalog II. Maler mit dem Grabstichel. Rubens und die Druckgraphik (Hrsg. Gerhard Bott), Museen der Stadt Köln, Köln 1977.

5 Rubens im Wettstreit mit Alten Meistern. Vorbild und Neuerfindung (Hrsg. Reinhold Baumstark, Mirjam Neumeister), Bayerische Staatsgemäldesammlungen, Alte Pinakothek, Ostfildern 2009. 
Beteiligten einen propagandistischen Stoff erster Ordnung dar: Er gestattete es, die heiklen Bedingungen europäischer Bündnispolitik in einen engen Zusammenhang mit der gemeinsamen Sache der Glaubensverteidigung zu rücken und die nun zum zweiten Mal seit 1529 erfolgte Rettung der Kaiserresidenz als Ergebnis göttlichen Willens auszugeben.

Das Wiener Ereignis ist in zwei monumentalen Darstellungen überliefert: im Heeresgeschichtlichen Museum Wien (Abb. 1) ${ }^{6}$ sowie in Schloss Friedenstein in Gotha (Abb. 2). ${ }^{7}$ Beide Gemälde konnten lange Zeit keinem Maler zugeschrieben werden. Die These einer Autorschaft Kesslers, wie sie der Autor beiden Museen anlässlich seines Vortrags beim Grazer Workshops 2018 vorgeschlagen hat, ist in einem intensiven Gedankenaustausch akzeptiert und durch den Nachweis eines einschlägigen Monogramms auf dem Wiener Gemälde, nämlich „S.K.“, nach gründlicher Prüfung erhärtet worden. ${ }^{8}$ Es liegt nahe, die stilistisch wie kompositorisch eng verwandte Gothaer Version in diesen Zusammenhang zu rücken. Weiterhin ist nicht auszuschließen, dass angesichts der Tragweite des Ereignisses für die europäische Geschichte noch weitere Versionen archivalisch nachgewiesen oder gar aufgefunden werden. Damit ist die Annahme, dass eine ganze Gruppe existiert haben könnte, zumindest nicht abwegig.

Die Perspektive des Wimmelbildes ist beiden Gemälden eigen: Der Vordergrund ist einschlägigen Protagonisten vorbehalten; in beiden Versionen ist dies der leicht identifizierbare polnische König, dem kompositorisch wie auch dem historischen Sachstand entsprechend der Rang des Vorkämpfers, des promachos, zukommt. Der Mittelgrund wird von dem registerartig entwickelten, in zahlreiche Einzelszenen untergliederten Kampfgeschehen eingenommen, so dass bei einem Maximum an personeller Dichte die Entfaltung einer schier unübersehbaren Fülle von Motiven bei detaillierter bis drastischer Erzählweise ermöglicht wird. Den abschließenden Hintergrund des Panoramas bildet ein Landschaftsprospekt mit der Stadt Wien inmitten der Donauebene: Hierbei tritt die topografisch genaue Wiedergabe hinter einer allgemeinen Erkennbarkeit zurück, garantiert durch zwei mittelalterliche, überaus markante Einzelmonumente, die freilich nicht detailgetreu wiedergegeben werden: die Bildsäule „Spinnerin am Kreuz" sowie der im Hintergrund aufragende Stephansdom, der über seine topografische Funktion hinaus als Symbol unangefochtener constantia im Spiegel neustoizistischer bzw. christlicher Deutung gesehen werden kann. ${ }^{9}$

Kesslers Schlachtenpanoramen basieren auf einer Bildauffassung, die einen deutlichen Gegensatz zu jener kartografisch orientierten, ${ }^{10}$ auf präzise Dokumentation zielenden Ereignisschilderung

6 Wien, Heeresgeschichtliches Museum, Inv. Nr. 1953/15/BI29623, Kessler Stephan (1622-1700), Belagerung und Entsatz der Stadt Wien im September 1683. Bezeichnet im Schriftband Mitte oben: „16 | die Belögerung Wien von Tirggn | 83“. Öl auf Leinwand, 238 x 390 cm; gerahmt 247 x 398 cm. Siehe Johann Christoph ALLMAYERBECK, Das Heeresgeschichtliche Museum Wien. Saal I. Von den Anfängen des stehenden Heeres bis zum Ende des 17. Jahrhunderts, Wien-Salzburg 1982, S. 63; Liselotte POPELKA, Heeresgeschichtliches Museum Wien, Graz-Köln 1988, S. 17; Manfried RAUCHENSTEINER, Manfred LITSCHER, Das Heeresgeschichtliche Museum in Wien, Graz-Wien 2000, S. 18; Das Heeresgeschichtliche Museum im Wiener Arsenal, Wien 2016, S. 29.

7 Gotha, Stiftung Schloss Friedenstein Gotha, Inv. Nr. SG 1213. Siehe Timo TRÜMPER, „(...) in einem elenden Wirtshaus als Tapete angetroffen“. Zur Geschichte eines monumentalen Schlachtenbildes mit der Befreiung Wiens 1683, Beiträge zur Residenzkultur. Festschrift für Bernd Schäfer, Gotha 2017 (Edition Residenzkultur, 5), S. 77-88. Freundliche Mitteilung Dr. Timo Trümper, Stiftung Schloss Friedenstein Gotha.

8 Monogrammiert auf Pistolentasche des Reiters im Bildmittelpunkt: „S.K“, undatiert (vor 1686). Freundliche Mitteilung OR Dr. Walter Kalina, Heeresgeschichtliches Museum Wien, 7. Jänner 2019.

9 Dazu allgemein Gerhard OESTREICH, Politischer Neustoizismus und Niederländische Bewegung in Europa (1965), Absolutismus (Hrsg. Walther Hubatsch), Darmstadt 1973 (Wege der Forschung, 314), S. 361-435.

10 Zum kartografischen Aspekt in der flämischen Malerei des 17. Jahrhunderts siehe Le peintre et larpenteur. Images 


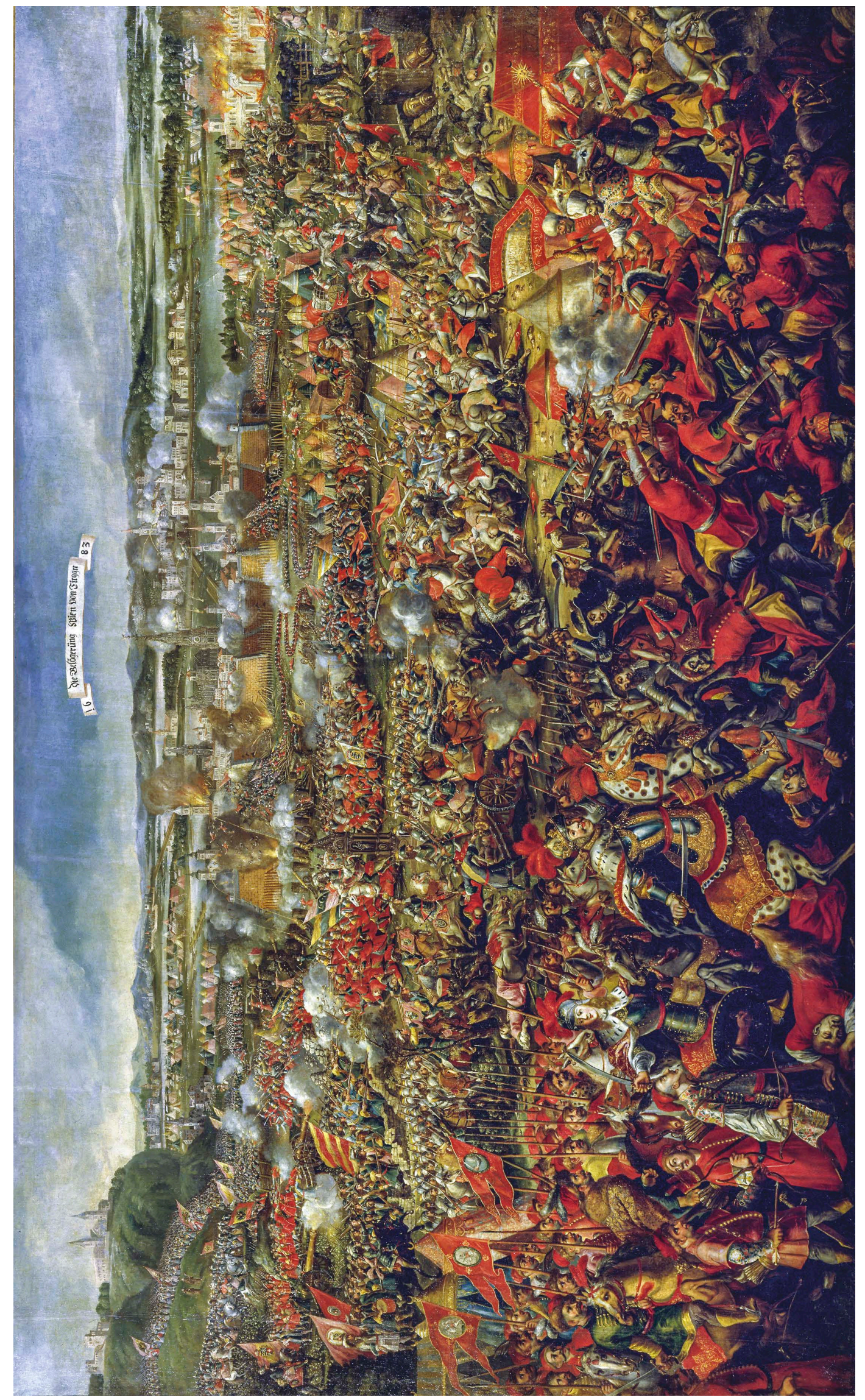

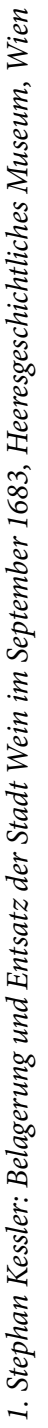




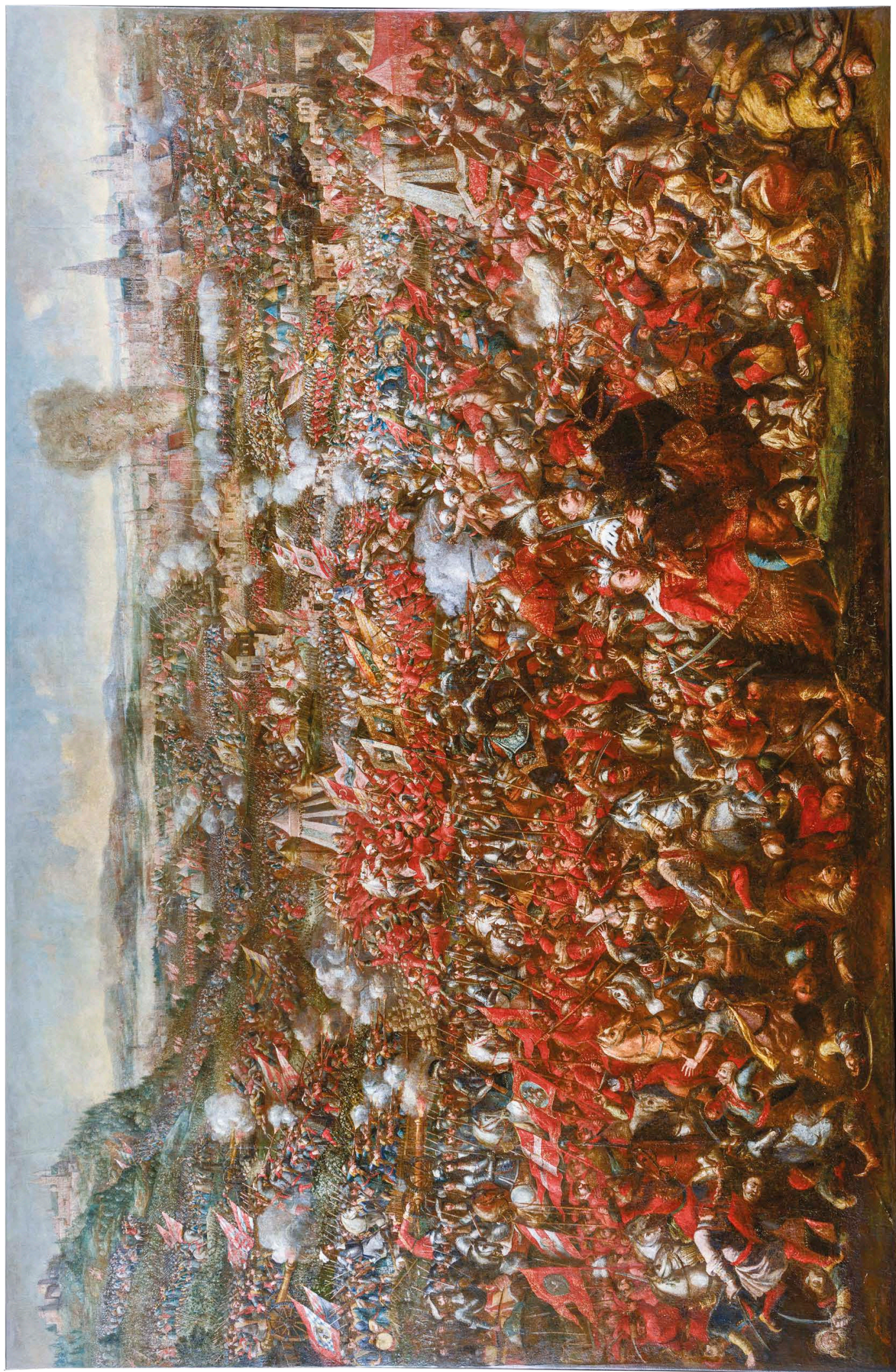

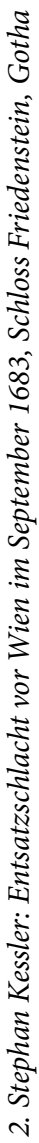


bei Pieter Snayers (1592-um 1667) ${ }^{11}$ darstellt, bei der ein möglichst umfassender, strategische wie taktische Aspekte einbeziehender Überblick aus der Vogelperspektive angestrebt wird. In dieser Erzählung haben auch Details aus dem flämischen Militärgenre ihren natürlichen, wiewohl untergeordneten Platz. Wer den Überblick behält, nimmt zugleich die Perspektive des militärisch Überlegenen ein. In diesem Sinne hatte Snayers seine themenverwandten, im Dienst der spanischen wie österreichischen Habsburger ausgeführten Großformate angelegt, die zu den bedeutendsten künstlerischen Reflexen frühneuzeitlicher Kriegführung überhaupt gerechnet werden müssen. In Snayers' Nachfolge steht Pierre Denis Martin (1663-1742), der eine Reihe von Waffenerfolgen Jan III. Sobieskis über die Osmanen, darunter auch den Entsatz von Wien 1683, in einer als Schlachtenchronik konzipierten Serie festhielt. ${ }^{12}$

Ungeachtet dieser Diskrepanzen dürfte sich Kessler in nicht geringerem Maße als getreuer Chronist verstanden haben. Indessen unterliegt seine Regie nicht dem Blickwinkel eines planvoll operierenden Mitglieds des Generalstabs. Vielmehr fordert Kesslers der Tradition des Wimmelbildes verpflichteter Bildaufbau Register für Register zur eingehenden Lektüre auf, ohne die Gesamthandlung aus dem Blick zu verlieren. Darin liegt eine Überwältigungsstrategie, die auf der Präsenz eines zwar räumlich geordneten, jedoch vor allem durch wild bewegte Masse und ausgeprägte Lokalfarbigkeit bestechenden Personals beider Kriegsparteien beruht. ${ }^{13} \mathrm{Im}$ Falle des unterlegenen Gegners ist bisweilen eine pointierte Karikierung zu bemerken. Ein weiterer Hauptaspekt besteht darin, dass das nahezu friesartig den allergrößten Teil des Bildraumes füllende Arrangement die Chance eröffnet, Kesslers Vorliebe für ausgewählte Zitate aus dem Rubens'schen Fundus buchstäblich Raum zu lassen und diese nach Art schmückender Vokabeln einzufügen. Die noch für Snayers essentielle Aufgabe, taktische Einsätze der einzelnen Waffengattungen wie Kavallerie, Infanterie und Artillerie im Sinne einer bereits hoch entwickelten Kriegswissenschaft plausibel zu demonstrieren, hat Kessler offensichtlich wenig bedeutet. Hingegen ist ihm der in prägnanten Szenen festgehaltene, mimisch wie gestisch ausgedrückte Furor des Kampfes - spätestens seit Leonardo da Vincis Entwürfen zur Anghiarischlacht ein elementares Anliegen der Schlachtenmalerei - weitaus wichtiger gewesen. Noch die Reaktion eines Betrachters auf die Gothaer Version von 1804 beweist, dass Kesslers Konzept aufgegangen ist. ${ }^{14}$

Dieses betont plakative Verfahren dürfte nicht zuletzt darauf gezielt haben, die grundlegende propagandistische Bildaussage hervorzuheben. Den vom Schrecken einer über Jahrhunderte bestehenden Gefahr geprägten christlichen Zeitgenossen hat sie klar vor Augen gestanden. Besonders chaotische Momente wie stürzende osmanische Reiter und Pferde ${ }^{15}$ bedeuten nicht allein eine effektvolle Steigerung der erzählerischen Spannung, sondern müssen allesamt als Allegorien auf

de Bruxelles et de lancien duché de Brabant (Hrsg. Véronique Van de Kerckhof, Helena Bussers, Véronique Bücken), Musées royaux des Beaux-Arts de Belgique, Bruxelles 2000.

11 Mapping Spaces. Networks of Knowledge in $17^{\text {th }}$ Century Landscape Painting (Hrsg. Ulrike Gehring, Peter Weibel), Zentrum für Kunst und Medientechnologie Karlsruhe, München 2014.

12 Schlossanlage Schleißheim. Amtlicher Führer (Bearb. Ernst Görz, Brigitte Lange), München 2005, S. 81.

13 Zur Tradition des Wimmelbildes im Kontext frühneuzeitlicher Schlachtenmalerei siehe Gisela GOLDBERG, Die Alexanderschlacht und die Historienbilder des bayerischen Herzogs Wilhelm und seiner Gemahlin Jacobaea für die Münchner Residenz, Bayerische Staatsgemäldesammlungen, München 1983 (Künstler und Werke, 5).

14 TRÜMPER 2017 (Anm. 7), S. 77.

15 Vergleichsmaterial bieten die entsprechenden Motive auf der Amazonenschlacht in der Alten Pinakothek, siehe BECKER 2005 (Anm. 3), S. 20-21, sowie Mirjam NEUMEISTER, Flämische Malerei. Alte Pinakothek, Ostfildern 2009 (Alte Pinakothek. Katalog der ausgestellten Gemälde, 3), S. 282-283. 
den Untergang des meistgefürchteten Glaubensfeindes gelesen werden, als der Kara Mustafas Scheitern vor Wien 1683 der Mit- und Nachwelt erschien. War schon die „Erste Türkenbelagerung“ 1529 im Spiegel der Radierung von Hanns Lautensack ${ }^{16}$ eine Wiederholung von Sanheribs Niederlage vor Jerusalem 701 v. Chr., so konnte auch der glückliche Ausgang der zweiten Heimsuchung durch den übermächtig scheinenden Gegner in diesem Sinne gedeutet werden - unter Hinzuziehung einer einschlägigen Bildformel, wie sie Rubens auf dem Wege der Reproduktionsgrafik der Nachwelt überlassen hatte. ${ }^{17}$

Wenn Kesslers Gemälde auch keine maximale topografische Verlässlichkeit bieten - die zeichenhafte Präsenz des Wiener Stadtpanoramas wurde als hinreichend betrachtet - so eröffnete ein Topos traditioneller Stadtwiedergaben, der Reichtum an Türmen, die willkommene Möglichkeit, einen versteckten Hinweis auf die Heimat des Malers unterzubringen: Auf der Gothaer Version ragt rechts vom Stephansdom ein zweitürmiger Kirchenbau auf, der in sichtbarer Konkurrenz zur Kathedrale die gesamte rechte Hälfte des Wiener Stadtbildes beherrscht und mehr als eine formelhafte Bereicherung der Silhouette darstellt. ${ }^{18}$ Erst auf den zweiten oder dritten Blick wird klar, dass es sich um den Brixener Dom handelt, wie er um 1700, also vor dem spätbarocken Neubau des Langhauses um die Mitte des 18. Jahrhunderts, ausgesehen hat. Für Kesslers Mitwelt war dies nichts Geringeres als eine zweite Signatur. Zur plakativen Inszenierung des Furors tritt das diskrete Lob der Herkunft des Malers: Tirol in Wien.

16 Fritz KORENY, Hanns Lautensack, Die Vernichtung von Sanheribs Heer als Allegorie auf die Niederlage der Türken vor Wien 1529, Radierung, 1558-1559, Wien, Albertina, Inv.-Nr. 1933/2281, Spätmittelalter und Renaissance (Hrsg. Artur Rosenauer), München-Berlin-London-New York 2003 (Geschichte der bildenden Kunst in Österreich, 3), Nr. 308, S. 569-571.

17 NEUMEISTER 2009 (Anm. 15), S. 272-275.

18 Auf die gerade hier signifikanten Unterschiede hat Dr. Walter Kalina, Wien, in besagter Mitteilung vom 7. Jänner 2019 ausführlich verwiesen und die m. E. plausible These eines Werkstattanteils vertreten. 


\section{Bibliographie}

ALLMAYER-BECK, Johann Christoph, Das Heeresgeschichtliche Museum Wien. Saal I. Von den Anfängen des stehenden Heeres bis zum Ende des 17. Jahrhunderts, Wien-Salzburg 1982.

BECKER, Ulrich, Pathosformel und Reproduktion. Beobachtungen zum Nachleben von Peter Paul Rubens im Oeuvre von Stephan Kessler, Stephan Kessler 1622-1700. Ein Tiroler Maler der Rubenszeit (Hrsg. Leo Andergassen, Helmut Stampfer), Diözesanmuseum Brixen, Brixen 2005, S. 15-23.

GOLDBERG, Gisela, Die Alexanderschlacht und die Historienbilder des bayerischen Herzogs Wilhelm und seiner Gemahlin Jacobaea für die Münchner Residenz, Bayerische Staatsgemäldesammlungen, München 1983 (Künstler und Werke, 5).

Das Heeresgeschichtliche Museum im Wiener Arsenal, Wien 2016.

KORENY, Fritz, Hanns Lautensack, Die Vernichtung von Sanheribs Heer als Allegorie auf die Niederlage der Türken vor Wien 1529, Radierung, 1558-1559, Wien, Albertina, Inv.-Nr. 1933/2281, Spätmittelalter und Renaissance (Hrsg. Artur Rosenauer), München-Berlin-London-New York 2003 (Geschichte der bildenden Kunst in Österreich, 3), Nr. 308, S. 569-571.

LIEBMINGER, Reinfried, Das Martyrium des Hl. Andreas von Stephan Kessler. Das Hochaltarbild in der Grazer Pfarrkirche St. Andrä, Graz 2017 (unpublizierte Masterarbeit).

Mapping Spaces. Networks of Knowledge in $17^{\text {th }}$ Century Landscape Painting (Hrsg. Ulrike Gehring, Peter Weibel), Zentrum für Kunst und Medientechnologie Karlsruhe, München 2014.

NEUMEISTER, Mirjam, Flämische Malerei. Alte Pinakothek, Ostfildern 2009 (Alte Pinakothek. Katalog der ausgestellten Gemälde, 3).

OESTREICH, Gerhard, Politischer Neustoizismus und Niederländische Bewegung in Europa (1965), Absolutismus (Hrsg. Walther Hubatsch), Darmstadt 1973 (Wege der Forschung, 314), S. 361-435.

Le peintre et l'arpenteur. Images de Bruxelles et de l'ancien duché de Brabant (Hrsg. Véronique Van de Kerckhof, Helena Bussers, Véronique Bücken), Musées royaux des Beaux-Arts de Belgique, Bruxelles 2000.

Peter Paul Rubens 1577-1640. Katalog II. Maler mit dem Grabstichel. Rubens und die Druckgraphik (Hrsg. Gerhard Bott), Museen der Stadt Köln, Köln 1977.

POPELKA, Liselotte, Heeresgeschichtliches Museum Wien, Graz-Köln 1988.

RAUCHENSTEINER, Manfried, LITSCHER, Manfred, Das Heeresgeschichtliche Museum in Wien, Graz-Wien 2000.

Rubens im Wettstreit mit Alten Meistern. Vorbild und Neuerfindung (Hrsg. Reinhold Baumstark, Mirjam Neumeister), Bayerische Staatsgemäldesammlungen, Alte Pinakothek, Ostfildern 2009.

Schlossanlage Schleißheim. Amtlicher Führer (Bearb. Ernst Görz, Brigitte Lange), München 2005.

Stephan Kessler 1622-1700. Ein Tiroler Maler der Rubenszeit (Hrsg. Leo Andergassen, Helmut Stampfer), Diözesanmuseum Brixen, Brixen 2005.

TRÜMPER, Timo, „(...) in einem elenden Wirtshaus als Tapete angetroffen“. Zur Geschichte eines monumentalen Schlachtenbildes mit der Befreiung Wiens 1683, Beiträge zur Residenzkultur. Festschrift für Bernd Schäfer, Gotha 2017 (Edition Residenzkultur, 5), S. 77-88.

\section{Abbildungsnachweis}

1: () Heeresgeschichtliches Museum, Wien.

2: (C) Schloss Friedenstein, Gotha. 


\title{
Svetovna zgodovina na "mrgoleči sliki «. \\ Stephan Kessler in Rešitev Dunaja leta 1683
}

\author{
Povzetek
}

S svojim načinom pripovedovanja, polnim veselja do nadrobnosti, in pogostim navezovanjem na pomembne avtoritete, kakršna je Rubens, si je južni Tirolec Stephan Kessler (1622-1700) zagotovil vidno mesto $v$ avstrijskem baročnem slikarstvu.

Kesslerjev opus se odlikuje z izjemnim bogastvom figur v tradiciji zgodnjenovoveških »mrgolečih slik» (Wimmelbilder), kakršne sta slikala Albrecht Altdorfer ali Jan Brueghel st. Ne glede na tehnične pomanjkljivosti v izvedbi, ki jih težko spregledamo, kaže Kesslerjevo obvladovanje te tradicije umetnika kot suverenega, dokumentarne in memorialne potrebe obdobja zadovoljujočega režiserja dramatičnih historičnih prizorov.

Za tisti čas značilen postopek, ki ga lahko pogosto dokažemo tudi v Kesslerjevih delih, je bila premišljena uporaba patetičnih formul iz del Petra Paula Rubensa. Iz te zmeraj dostopne motivne zakladnice, ki je zagotavljala uspešne dramatične učinke, je lahko Kessler redno črpal s pomočjo kakovostne antwerpenske prevodne grafike.

$\mathrm{V}$ ta kontekst sodi upodobitev dogodka, pomembnega za svetovno zgodovino, rešitve Dunaja leta 1683, ko je vojaška intervencija pod vodstvom poljskega kralja Jana III. Sobieskega dokončno ustavila nadaljnje turško prodiranje $\mathrm{v}$ Evropo in, po drugi strani, pomagala v pripravah na habsburško osvajanje jugovzhodne Evrope.

Seveda je bil ta trenutek, prav tako dramatičen kot krvav, večkrat predmet historičnega slikarstva. Ker so turški poraz pred Dunajem leta 1529 sodobniki povezovali s porazom asirskega kralja Sanheriba pred Jeruzalemom leta 701 pred Kristusom, je bila že od vsega začetka prisotna zgodovinsko-svetopisemska dimenzija.

Monumentalni, slogovno in kompozicijsko tesno sorodni različici, hranjeni v Vojnozgodovinskem muzeju na Dunaju in v gradu Friedenstein v Gothi, posebej izstopata zaradi svojih skoraj ljudskih, plakativnih potez. Avtorsko sliki doslej nista bili opredeljeni. Ujemanja v kompoziciji z gosto naslikanimi množicami in v obravnavi detajlov kažejo, da gre za deli istega avtorja, zaradi specifičnega rokopisa, ki ga razkrivata, pa lahko obe sliki prepričljivo pripišemo Kesslerju, saj je za njegov slog značilna očitna diskrepanca med učinkovito režijo na eni in obrtniško nebogljeno risbo figur na drugi strani.

Tudi Kesslerjevo južnotirolsko poreklo se je v obliki skritega namiga znašlo v kompoziciji: nanj kaže podoba briksenske stolnice, kakršna je bila okrog leta 1700, vstavljena v mestno veduto Dunaja na verziji, hranjeni v Gothi.

Atribucija Kesslerju je bila tako na Dunaju (dr. Walter Kalina) kakor tudi v Gothi (dr. Timo Trümper) sprejeta kot hvale vredna. $V$ tem kontekstu predstavlja izjemno srečno naključje najdba monograma SK ob natančnem pregledu dunajske slike, ki ga je izvedel dr. Kalina. S tako potrjeno atribucijo je bila zapolnjena tudi vrzel $\mathrm{v}$ dosedanjem védenju. 